\title{
Interaction between stress and the BDNF Val66Met polymorphism in depression: a systematic review and meta-analysis
}

\author{
Georgina M Hosang ${ }^{1,2^{*}}$, Celia Shiles ${ }^{3}$, Katherine E Tansey ${ }^{2,4}$, Peter McGuffin ${ }^{2}$ and Rudolf Uher ${ }^{2,5}$
}

\begin{abstract}
Background: Major depression is a disabling psychiatric illness with complex origins. Life stress (childhood adversity and recent stressful events) is a robust risk factor for depression. The relationship between life stress and Val66Met polymorphism in the brain-derived neurotrophic factor (BDNF) gene has received much attention. The aim of the present work was to review and conduct a meta-analysis on the results from published studies examining this interaction.
\end{abstract}

Methods: A literature search was conducted using PsychINFO and PubMed databases until 22 November 2013. A total of 22 studies with a pooled total of 14,233 participants met the inclusion criteria, the results of which were combined and a meta-analysis performed using the Liptak-Stouffer z-score method.

Results: The results suggest that the Met allele of BDNF Val66Met significantly moderates the relationship between life stress and depression $(P=0.03)$. When the studies were stratified by type of environmental stressor, the evidence was stronger for an interaction with stressful life events $(P=0.01)$ and weaker for interaction of BDNF Val66Met with childhood adversity $(P=0.051)$.

Conclusions: The interaction between BDNF and life stress in depression is stronger for stressful life events rather than childhood adversity. Methodological limitations of existing studies include poor measurement of life stress.

Keywords: Stress, Life events, Childhood maltreatment, Childhood adversity, Child abuse, Depression, Brain-derived neurotrophic factor, BDNF, rs6265, Gene-environment interaction

\section{Background}

Major depression is a prevalent psychiatric illness that is associated with considerable morbidity and mortality [1]. Much research has been dedicated to uncovering its aetiology with mixed success. Environmental factors, such as childhood adversity [2,3] and stressful life events [4-6] have been associated with the onset and course of major depression. However, not everyone exposed to such adversity develops this illness or relapses [6]; this has led researchers to explore stress vulnerability factors, including interactions with genetic influences [7]. The brain-derived

\footnotetext{
*Correspondence: g.hosang@gold.ac.uk

'Psychology Department, Goldsmiths, University of London, New Cross, London SE14 6NW, UK

${ }^{2}$ MRC Social, Genetic and Developmental Psychiatry Centre, Institute of Psychiatry, King's College, London, De Crespigny Park, London SE5 8AF, UK Full list of author information is available at the end of the article
}

neurotrophic factor $(B D N F)$ gene has been implicated in stress vulnerability [8]. Both variation in this gene sequence and stress exposure influence expression and intracellular trafficking of the BDNF protein. Stress is hypothesised to cause a reduction in BDNF (protein) levels in the brain (particularly in regions linked to emotion), which alters mood and may cause depression [9]. Consequently, the $B D N F$ gene has been identified as a stress vulnerability candidate generating much research, which has yet to be reviewed or synthesised.

The purpose of the present work was to systematically review and perform a meta-analysis on studies that have investigated the interaction between the Val66Met polymorphism in the BDNF gene and life stress (childhood adversity and stressful life events) in depression.

Major depression has a lifetime prevalence of $17 \%$ [10] and is diagnosed based on the presentation of depressive

\section{Biomed Central}


symptoms (for example, low mood, sleep disturbance and suicidal behaviours) that last at least 2 weeks [1]. Depressive episodes are also experienced by individuals suffering from bipolar disorder, although the defining feature of this condition is mania (symptoms include, elation, grandiosity and irritability) [11].

Major depression is considered one of the most burdensome diseases in the world [12] and it is projected that this illness will be the second leading cause of disease burden for developed countries by 2020 [13]. Better understanding of the aetiology of this debilitating disorder is urgently required so that steps can be taken to reduce the burden on the individual, their families and society as a whole.

\section{Life stress and depression}

There is a wealth of literature concerned with the impact of life stress and depression, with studies focusing on childhood adversity and stressful life events.

\section{Childhood adversity}

Childhood adversity is defined as stressful experiences that occur early in life; examples include abuse (such as sexual and physical abuse), neglect (failure of caretakers to provide the child with basic needs such as food or support), parental death and divorce. Significantly higher rates of childhood adversity are reported by adults with major depression compared to the general population [14]. Childhood adversity is also associated with worse course of depression, including lack of treatment response as well as more chronic and more frequent episodes [15].

Most studies in this area rely on retrospective reporting which is associated with various biases calling into question the validity and reliability of their findings. A recent study showed that whether childhood maltreatment is assessed prospectively (child protection database) or retrospectively (self-report), it is still significantly associated with major depression to a similar degree [16]. Moreover, Widom and colleagues [17] prospectively followed children who were abused or neglected (identified through court records), and found that as adults these individuals were at increased risk of major depression compared to matched controls.

Childhood adversity is a non-specific risk factor and has been linked to other emotional problems [18], psychiatric illnesses $[16,19,20]$ and physical disorders $[21,22]$. A better understanding of the specific mechanisms that underlie the childhood adversity/depression association is needed.

\section{Stressful life events}

Stressful life events are described as circumstances that have a negative impact on an individual (for example, stress) that occur close to the onset or relapse of the illness [23]. Stressful events such as bereavement and divorce are common, but people's responses to such events vary, some appear to cope well and others spiral into a depressive episode [6,24]. Although it has been shown that stressful life events cluster before a depressive episode or worsening of symptoms [4,25], there is strong evidence that one such event is sufficient to trigger an episode onset [26].

Investigating the relationship between stressful events and depression is not as straightforward as establishing whether an event occurred or not, various elements must be considered. Determining the direction of association is important, are stressful events generated by the individual and influenced by depressive symptoms (dependent events), or is it that such events occur 'out of blue' and trigger depressive episodes (independent events)? Establishing the event severity is essential as their impact differs between individuals and is dependent on circumstance. These key issues are addressed with the collection of contextual and biographical information best achieved using semi structured interviews [27-29]. Studies employing this method have consistently shown that severe independent events are linked to the onset, relapse and exacerbation of depressive symptoms $[5,25,30]$, illustrating a causal relationship.

There is strong evidence for an association between life stress and depression, research now focuses on identifying stress vulnerability factors in depression including genetic factors [31,32].

\section{Gene/environment interactions}

Genetic sensitivity to one's environment or geneenvironment interactions [33], has spurred much mental health research following Caspi and colleagues' [31] study. Their results showed that the low expressing short allele of the serotonin-transporter-linked promoter region polymorphism (5-HTTLPR; a functional variant in the serotonin transporter gene) increased depressive symptoms, rates of diagnosed depression and suicidality following exposure to stressful events and childhood maltreatment [31].

Many studies that attempted to replicate these results adopted different designs using divergent samples/ populations, which resulted in mixed success [34,35]. The reviews $[7,28,36]$ and meta-analytic studies $[15,37]$ published on this topic suggest that the interaction is strongest between 5-HTTLPR and childhood adversity, rather than recent stressful events [37]. Life stress assessment is crucial, with studies that used objective measures or semi structured interviews rather than crude selfreport questionnaires detecting the interaction with the 5HTTLPR variant [37]. The relationship between life stress and the serotonin transporter gene is fairly consistent for persistent and recurrent depression [14,38,39].

Other genes have been implicated in stress vulnerability including the CRHR1 [40,41], FKBP5 [42] and BDNF [43] genes. The relationship between the Val66Met variant in the $B D N F$ gene and stress in depression has been widely 
researched and thus a systematic review and meta-analysis is warranted to synthesise the literature.

\section{BDNF and life stress in depression}

BDNF is a protein involved in the proliferation, differentiation and survival of neuronal cells and regulation of synaptic plasticity and connectivity in the adult brain [44]. Research suggests that BDNF may also be influential in sensitivity to stress.

According to the 'neurotrophic hypothesis' of depression $[8,45]$, stress reduces BDNF activity, which results in decreased function in limbic brain regions (for example, hippocampus) involved in emotion processing and cognition. This reduction in turn is posited to be associated with depressed mood; while antidepressant therapy is hypothesised to reverse this effect $[9,45]$. There is evidence that stress and trauma result in decreased BDNF levels in both rodents $[46,47]$ and humans $[48,49]$. The findings from several meta-analyses show that lower serum BDNF levels are detected among depressed patients relative to controls but these levels are normalised with antidepressant treatment [50,51]. There is some debate surrounding the link between BDNF, antidepressants and (hippocampal) neurogenesis (see [52] for more a detailed discussion). Together the evidence presented generally supports the 'neurotrophic hypothesis' of depression.

A single nucleotide polymorphism (SNP) in the $B D N F$ gene (that is, Val66Met; rs6265) has been shown to influence the activity of the BDNF protein. This SNP results in the substitution of valine (Val) to methionine (Met) [53]. Although the BDNF gene consists of several polymorphisms many are in high linkage disequilibrium and highly correlated $[54,55]$.

The Met allele of the BDNF Val66Met polymorphism has been linked with reduced BDNF activity [44], memory impairment [56] and harm avoidance [57]. Individuals with at least one Met allele of this SNP and at high risk of affective disorders (co-twin diagnosed with a mood disorder) have elevated evening cortisol levels, which suggests altered stress response [58].

Transgenic mice that are Met carriers of BDNF Val66Met exhibit increased anxiety-related behaviours under stress conditions [59], as well as decreased BDNF levels in the hippocampus [60], in line with the 'neurotrophic hypothesis'.

The research highlighted thus far presents a case for a significant interaction between BDNF Val66Met and life stress in depression. The purpose of the current paper is to systematically review and meta-analyse the literature concerned with this interaction addressing the specific question: 'is there a significant interaction between the Met variant of BDNF Val66Met and life stress in depression?'

\section{Methods}

\section{Data sources and search strategy}

The systematic review was performed according to the 'Preferred Reporting Items for Systematic Reviews and Meta-Analyses' (PRISMA) guidelines [61]. The literature searches were undertaken using PsychINFO, and PubMed up until 22 November 2013 for original research studies. The search terms were synonyms for depression, life stress and the BDNF Val66Met polymorphism (see Table 1). These terms were searched for in the articles' titles, keywords, tests and measures. Only papers published in the English language were considered for inclusion. The reference lists of identified studies were also searched by hand for relevant papers.

\section{Eligibility criteria}

The eligibility criteria were stipulated as follows: utilisation of human participants; depression (illness onset or relapse) or its symptoms were assessed; focus on BDNF Val66Met polymorphism (rs6265); childhood adversity and/or stressful life events (a range of types of events) were assessed; the interaction between stress and the $B D N F$ Val66Met polymorphism was investigated. Studies in gross departure of Hardy-Weinberg equilibrium were excluded (for example, $P \leq 0.001$ ).

\section{Data extraction}

Variety of data were extracted from included studies in accordance with other gene-environment interaction reviews $[37,62]$ (see Table 2). When publications reported results for both childhood adversity and recent stressful life events they were included in each environmental stressor group; but the results for each stressor were averaged and included in the overall analyses. The data was extracted and confirmed by two authors (GMH and KET). Where studies used multiple life stress and/or depression measures, the data yielded from interviews was included in the analyses. If the information required was not reported or unclear the authors of the original article were contacted.

\section{Quality appraisal of studies}

The methodological quality of included studies was evaluated against a quality checklist, derived from the STREGA ('Strengthening the Reporting of Genetic Association Studies') and STROBE ('Strengthening the Reporting of Observational Studies in Epidemiology') checklists [63,64], which have been used by other gene-environment interaction meta-analyses [37].

In accordance with current guidelines and previous reviews of gene-environment interaction studies [37], the studies were not weighted by quality scores or excluded based on low scores, but the information is presented in Additional file 1 for readers' evaluation. 
Table 1 Terms used for literature search

\begin{tabular}{ll}
\hline Keyword(s) & Additional search terms used \\
\hline 1. Depression & $\begin{array}{l}\text { Depressive disorder OR major depressive } \\
\text { disorder OR depression OR major depression OR } \\
\text { unipolar depression OR depressive symptoms }\end{array}$ \\
2. Life stress & $\begin{array}{l}\text { Stressful life events, OR life events OR negative } \\
\text { life events OR adverse life events OR events OR } \\
\text { stress OR stressors OR childhood maltreatment } \\
\text { OR childhood adversity OR childhood stress OR } \\
\text { child abuse OR child neglect OR adversity }\end{array}$ \\
$\begin{array}{l}\text { 3. BDNF Val66Met } \\
\text { polymorphism }\end{array}$ & OR rs6265 OR Val66Met \\
\hline
\end{tabular}

\section{Statistical analyses}

The Liptak-Stouffer z-score method was used to combine studies at the level of significance tests with the results weighted by sample size. This approach has been used by another meta-analysis of gene-environment interactions [37]. This method involves a number of steps. First, the $P$ values from the eligible studies were extracted and converted to one-tailed values, with those less than 0.50 indicating greater Met allele stress sensitivity and $P$ values of greater than 0.50 corresponding to Val allele stress sensitivity in depression. Second, these $P$ values were transformed into z-scores using a standard normal curve. Positive $\mathrm{z}$-scores were assigned to $P<0.50$ and negative $\mathrm{z}$-scores corresponded to $P>0.50$. Third, the $\mathrm{z}$-scores were combined and weighted to take into account the study sample size. The following formula was used to do this:

$$
Z w=\frac{\sum_{i=1}^{k} w_{i} z_{i}}{\sqrt{\sum_{i=1}^{k} w_{i}^{2}}}
$$

The weighting factor $w_{i}$ corresponds to each study's sample size, $\mathrm{k}$ indicates the number of total studies, and $\mathrm{Z}_{\mathrm{i}}$ corresponds to the $\mathrm{z}$-scores of individual studies. $\mathrm{Z}_{\mathrm{w}}$, which is the outcome of this test, follows a standard normal distribution and thus related probability corresponds with a standard normal distribution table. This approach was used on the overall and stratified analyses.

Sensitivity analyses were undertaken to determine whether the results were considerably influenced by any single study; the procedure involved systematically excluding each study and recalculating the significance of the result.

To assess the potential impact of publication bias on the meta-analysis results the fail-safe $\mathrm{N}$ was calculated for all analyses. In line with Karg and colleagues [37], the number of studies with a $P$ value equal to 0.50 and a sample size of 647 (average sample size of the studies analysed in the overall meta-analysis) were calculated that would need to be included in the weighted Liptak-Stouffer analyses to obtain a non-significant result. The ratio between the fail-safe and the actual number of studies published provides an estimation of the possibility of publication bias effecting our findings.

\section{Results}

Study selection

A combination of the predefined search terms (depression + life stress + BDNF Val66Met) resulted in 1,019 hits; after duplicates were removed, 236 studies remained (see Figure 1). The abstracts of these articles were reviewed and those studies that reported on the interaction between life stress and BDNF Val66Met in depression were included. No existing systematic or meta-analytic reviews were found.

\section{Overall evidence for BDNF $\times$ stress in mood disorders}

Out of the 22 studies included, 8 reported a significant interaction between life stress (either life events or child adversity) and the Met variant of BDNF Val66Met in depression (see Table 2 and Figure 2).

Other studies provided partial evidence of a significant stress $\times B D N F$ for specific types of depression [65], childhood adversity $[66,67]$ or detected a gender specific effect [68].

Several studies found a significant interaction between life stress and $B D N F$ in depression using a Val recessive model [69-71]. The allele frequencies of the BDNF Val66Met polymorphism differs between ethnic groups, with the Met allele frequency highest among Asian populations [72]. Two of these studies used either a Han Chinese sample [69], or a cohort with mixed ethnicity [71], which may have contributed to the unusual finding with a Val recessive model.

\section{Meta-analysis result}

Combining the results from the identified studies with a total of 14,233 participants showed that the interaction between the Met variant of the BDNF Val66Met polymorphism significantly moderates the relationship between life stress and depression $(P=0.03)$. When findings from studies that used Caucasian samples were meta-analysed separately (to account for the potential confounding effect of population stratification), the results failed to reach conventional level of significance although they were in the expected direction $(P=0.07)$.

The sensitivity analyses showed that the results remained significant after removing each study in turn (>0.004 $P<0.049)$ with the exception of 4 studies [43,73-75]. In terms of publication bias, to make these results non-significant $(P=0.05)$, more than 11 unpublished or undiscovered studies with an average sample of 657 participants reporting a non-significant finding $(P=0.50)$ would need to exist. This corresponds to a failsafe ratio of 2 studies not included in the meta-analysis for every included study. 
Table 2 Summary of studies examining the interaction between life stress and brain-derived neurotrophic factor (BDNF) Val66Met in depression

\begin{tabular}{|c|c|c|c|c|c|c|c|c|c|}
\hline Source & $N$ & Females, $\%$ & $\begin{array}{l}\text { Age at study } \\
\text { assessment } \\
\text { (Mean or range) }\end{array}$ & Ancestry & Study design & Stressor & Life stress assessment & Outcome & $\begin{array}{l}\text { Averaged } \\
\text { one-sided } \\
P \text { value }\end{array}$ \\
\hline Kaufman et al., 2006 [79] & 194 & 51 & 9.3 years & Mixed & Cross-sectional & Childhood adversity & Children taken into care & Depressive symptoms & 0.6765 \\
\hline Kim et al., 2007 [43] & 732 & 59 & 65 years and over & East Asian & Cross-sectional & Stressful life events & $\begin{array}{l}\text { Researcher-administered } \\
\text { questionnaire }\end{array}$ & Depression diagnosis & 0.000315 \\
\hline Wichers et al., 2008 [73] & 464 & 100 & 18 to 46 years & European & Longitudinal twin study & Childhood adversity & Questionnaire & Depressive symptoms & 0.009 \\
\hline Aguilera et al., 2009 [66] & 470 & 55 & 22.9 years & European & Cross-sectional & Childhood adversity & Questionnaire & Depressive symptoms & 0.637 \\
\hline Bukh et al., 2009 [82] & 290 & 66 & 38.5 years (median) & European & Case only & Stressful life events & Interview & Depression onset & 0.004 \\
\hline Gatt et al., 2009 [88] & 374 & 51 & 36.2 years & European & Cross-sectional & Childhood adversity & Questionnaire & Depressive symptoms & 0.272 \\
\hline Hosang et al., 2010 [75] & 1,085 & 62 & 37.83 years & European & Case-control & Stressful life events & $\begin{array}{l}\text { Researcher-administered } \\
\text { questionnaire }\end{array}$ & Bipolar disorder relapse & 0.02 \\
\hline Lavebratt et al., 2010 [68] & 950 & 58 & 20 to 64 years & European & Longitudinal survey & $\begin{array}{l}\text { Childhood adversity } \\
\text { and Stressful life events }\end{array}$ & Questionnaire & Depressive diagnosis & 0.5 \\
\hline Nederhof et al., 2010 [80] & 1,096 & 53 & 16.13 years & European & Longitudinal study & Childhood adversity & $\begin{array}{l}\text { Questionnaires } \\
\text { and interviews }\end{array}$ & Depressive symptoms & 0.3525 \\
\hline Carver et al., 2011 [76] & 133 & 74 & 18.71 years & Mixed & Cross-sectional & Childhood adversity & Questionnaire & Depression diagnosis & 0.01 \\
\hline Elzinga et al., 2011 [81] & 1,435 & 69 & 42.2 years & European & Case only & $\begin{array}{l}\text { Childhood adversity } \\
\text { and stressful life events }\end{array}$ & Interview & $\begin{array}{l}\text { Depression diagnosis } \\
\text { and symptom severity }\end{array}$ & 0.4325 \\
\hline Juhasz et al., 2011 [74] & 1,269 & 70 & 34.04 years & Caucasian & Cross-sectional & $\begin{array}{l}\text { Childhood adversity } \\
\text { and stressful life events }\end{array}$ & Questionnaire & Depression diagnosis & 0.13165 \\
\hline Chen et al., 2012 [69] ${ }^{a}$ & 780 & 51 & 13.6 years & Han Chinese & Longitudinal twin study & Stressful life events & Questionnaire & Depressive symptoms & 0.9875 \\
\hline Grabe et al., $2012[70]^{a}$ & 2,035 & 53 & 55.6 years & Caucasian & Case only & Childhood adversity & Questionnaire & Depressive symptoms & 0.785 \\
\hline Herbert et al., 2012 [83] & 279 & 100 & 36.8 years & Caucasian & Longitudinal study & Stressful life events & Interview & Depression diagnosis & 0.0935 \\
\hline Perea et al., 2012 [77] & 302 & 50 & 18 years & $\begin{array}{l}\text { Mixed } \\
\text { (Columbian } \\
\text { population) }\end{array}$ & Cross-sectional & $\begin{array}{l}\text { Childhood adversity } \\
\text { and stressful life events }\end{array}$ & Questionnaire & Depressive symptoms & 0.01725 \\
\hline Quinn et al., 2012 [65] & 240 & 59 & 40.01 years & Unknown & Cross-sectional & Childhood adversity & Questionnaire & $\begin{array}{l}\text { Melancholic subtype of } \\
\text { depression diagnosis }\end{array}$ & 0.5 \\
\hline Caldwell et al., $2013[71]^{a}$ & 124 & 66 & 21.97 years & Mixed & Cross-sectional & Childhood adversity & Questionnaire & Depressive symptoms & 0.8705 \\
\hline Comasco et al., 2013 [67] & 1,393 & 50 & 17 to 18 years & European & Cross-sectional & Childhood adversity & Questionnaire & Depressive symptoms & 0.251 \\
\hline La Greca et al., 2013 [78] & 116 & 54 & 8.85 years & Mixed & Cross-sectional & Childhood adversity & Questionnaire & Depressive symptoms & 0.167833 \\
\hline Jiang et al., 2013 [89] & 238 & 73 & 61.7 years & Caucasians & Cross-sectional & Stressful life events & $\begin{array}{l}\text { Carer of person } \\
\text { with dementia }\end{array}$ & Depressive symptoms & 0.9805 \\
\hline Brown et al., 2013 [85] & 234 & 100 & 37 years & Caucasian & Longitudinal study & $\begin{array}{l}\text { Childhood adversity } \\
\text { and stressful life events }\end{array}$ & Interview & Depressive episode onset & 0.431 \\
\hline Total & 14,233 & & & & & & & & \\
\hline Average sample size & 647 & & & & & & & & 0.03 \\
\hline
\end{tabular}




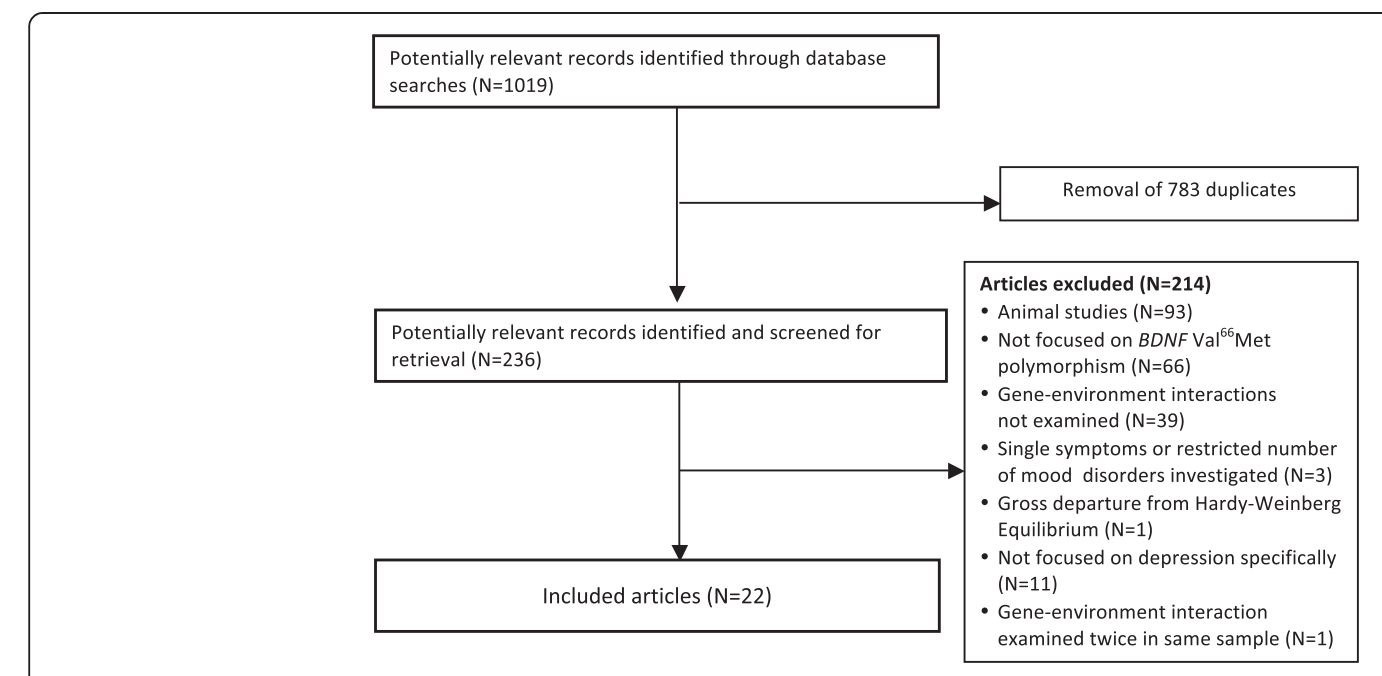

Figure 1 Flow diagram of studies considered for inclusion. This flow diagram depicts each step in the process of study selection.

Since there is evidence for the differential interaction effect with child adversity and stressful life events with other SNPs (for example, 5-HTTLPR [43]), the results pertaining to the impact of these types of stressors and the $B D N F$ gene were examined.

\section{Childhood adversity}

In all, 16 studies explored the interaction between childhood adversity and $B D N F$ in depression, 4 reported a significant effect $[73,74,76,77]$ and 5 showed partial support for this interaction [65-68,78] (see Table 3).

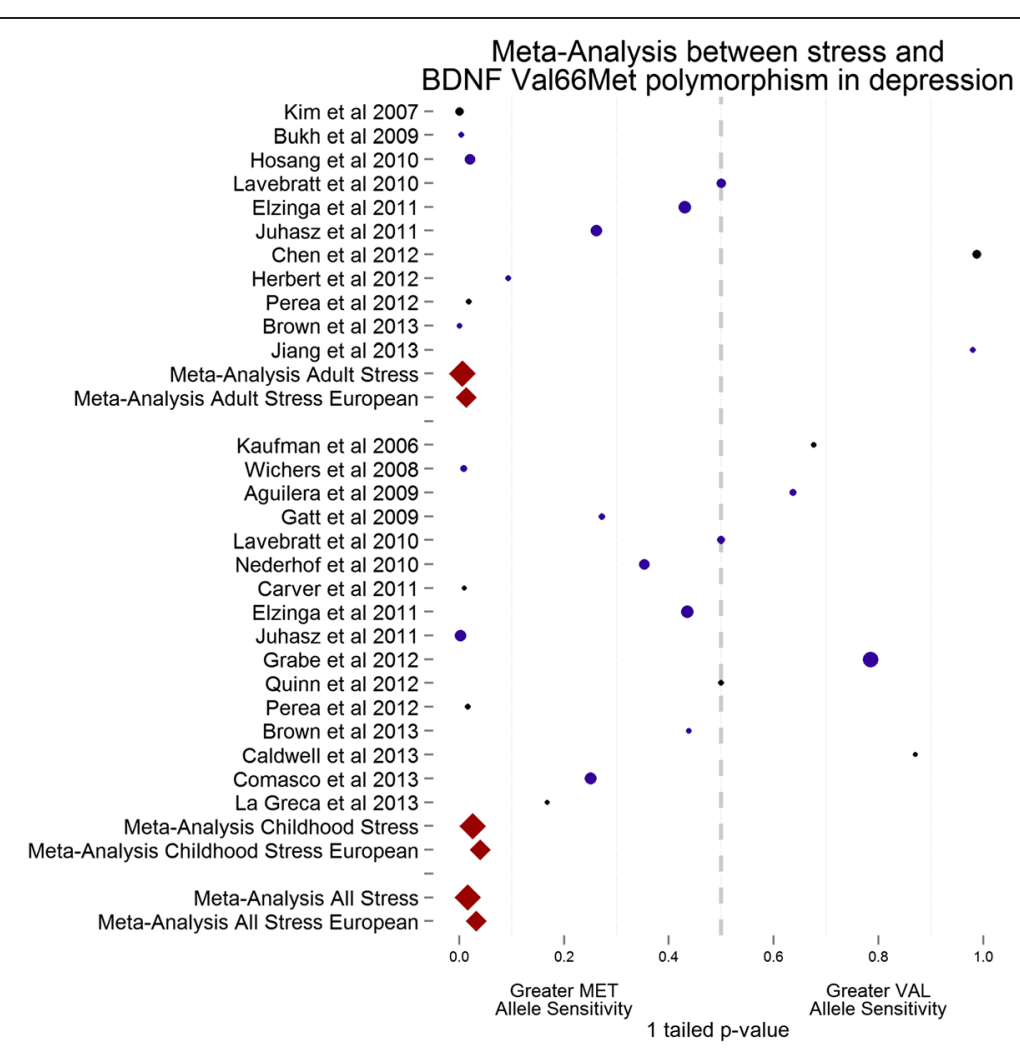

Figure 2 Forest plot for included studies examining the interaction between the Met variant of the brain-derived neurotrophic factor (BDNF) gene and life stress in depression. 
Table 3 Studies included in the childhood adversity meta-analysis

\begin{tabular}{lll}
\hline Source & Sample size & One-sided $\boldsymbol{P}$ value \\
\hline Kaufman et al., 2006 [79] & 194 & 0.6765 \\
Wichers et al., 2008 [73] & 464 & 0.009 \\
Aguilera et al., 2009 [66] & 470 & 0.637 \\
Gatt et al., 2009 [88] & 374 & 0.272 \\
Lavebratt et al., 2010 [68] & 642 & 0.5 \\
Nederhof et al., 2010 [80] & 1,096 & 0.3525 \\
Carver et al., 2011 [76] & 133 & 0.01 \\
Juhasz et al., 2011 [74] & 1,269 & 0.0018 \\
Elzinga et al., 2011 [81] & 1,435 & 0.435 \\
Grabe et al., 2012 [70] & 2,035 & 0.785 \\
Quinn et al., 2012 [65] & 240 & 0.5 \\
Perea et al., 2012 [77] & 302 & 0.016 \\
La Greca et al., 2013 [78] & 116 & 0.167833 \\
Caldwell et al., 2013 [71] & 124 & 0.8705 \\
Comasco et al., 2013 [67] & 1,393 & 0.251 \\
Brown et al., 2013 [85] & 234 & 0.431 \\
Total & 10,521 & \\
Average sample size & 658 & 0.051 \\
\hline
\end{tabular}

For instance, rather than investigating child adversity as one overarching construct, Aguilera and colleagues [66] focused on different types and only found a significant interaction between child sexual abuse and $B D N F$. Given the acknowledged heterogeneity in major depression [1], Quinn and associates [65] explored the impact of the child adversity-BDNF interaction on different subtypes of the disorder and found a significant effect for non-melancholic depression only.

The childhood adversity measures used by studies is particularly noteworthy, with all of the those reporting a significant interaction relying on questionnaires, while many of those studies not reporting an effect utilised more objective methods [79-81].

\section{Childhood adversity: meta-analysis results}

In meta-analysing the results from included studies with a combined sample of 10,521 individuals, a trend towards a significant interaction between childhood adversity and $B D N F$ in depression was detected $(P=0.051)$, but was not improved on when only those studies with Caucasian samples were analysed $(P=0.08)$.

In undertaking sensitivity analyses, the results remained non-significant after removing each study in turn $(>0.052$ $P<0.27)$, with the exception of $6[66,68,70,71,79,81]$.

\section{Stressful life events}

The stressful events-BDNF interaction in depression was investigated in 11 studies using a combined sample of 7,594 individuals; 5 uncovered a significant effect (see Table 4). The majority of these studies used either researcher-administered questionnaires $[43,75]$ or interviews [82], while the non-replicating studies relied on self-report checklists with one exception [83].

Bipolar disorder was the focus of one study [75], which found that the effect of stressful life events on episodes of bipolar depression were significantly greater in Met allele carriers (Met/Met and Val/Met) relative to those with the $\mathrm{Val} / \mathrm{Val}$ genotype. However, no such pattern was reported for manic episodes [75].

\section{Stressful life events: meta-analysis results}

A significant interaction between stressful life events and the Met variant of $B D N F$ Val66Met $(P=0.01)$ was found; the results remained significant when the analyses were restricted to studies using Caucasian samples $(P=0.027)$.

Sensitivity analysis showed the $P$ value remained significant with the exclusion of each study from the analysis $(>0.001 P<0.023)$, except for $2[43,75]$.

For this result to be non-significant $(P=0.05)$ more than 14 unpublished or unidentified studies need to exist with an average sample of 690 participants and a non-significant result $(P=0.50)$. This corresponds to a fail-safe ratio of 1 study not included for every study entered into the meta-analysis.

\section{Discussion}

A total of 22 studies with a combined sample of 14,233 participants met the eligibility criteria, 8 of which reported a significant interaction between life stress and the Met variant of $B D N F$ Val66Met. The overall meta-analysis found evidence for a significant interaction between life stress and BDNF in depression using a Met dominant

Table 4 Studies included in the stressful life events meta-analysis

\begin{tabular}{lll}
\hline Source & Sample size & One-sided $\boldsymbol{P}$ value \\
\hline Kim et al., 2007 [43] & 732 & 0.000315 \\
Bukh et al., 2009 [82] & 290 & 0.004 \\
Hosang et al., 2010 [75] & 1,085 & 0.02 \\
Lavebratt et al., 2010 [68] & 950 & 0.5 \\
Juhasz et al., 2011 [74] & 1,269 & 0.2615 \\
Elzinga et al., 2011 [81] & 1,435 & 0.43 \\
Chen et al., 2012 [69] & 780 & 0.9875 \\
Perea et al., 2012 [77] & 302 & 0.0185 \\
Herbert et al., 2012 [83] & 279 & 0.0935 \\
Jiang et al., 2013 [89] & 238 & 0.9805 \\
Brown et al., 2013 [85] & 234 & 0.0004 \\
Total & 7,594 & \\
Average sample size & 690 & 0.01 \\
\hline
\end{tabular}


model. When the analyses were stratified by type of stressor, the results were strongest for stressful life events while the effect of childhood adversity failed to reach conventional levels of significance.

These findings help build a lifespan model of causation for major depression focusing on several gene-stress interactions. Research shows that childhood adversity (distal and stable risk factor) significantly interacts with the short allele of the 5-HTTLPR [37], while the findings from this meta-analysis suggest that the stressful life events (proximal and provoking factor) significantly interacts with the Met variant of $B D N F$ in depression.

It has also been postulated that individuals who are genetically sensitivity to adverse experiences (for example, Met carriers) may benefit most from positive environments or even the lack of adversity, under the 'differentially susceptibility' hypothesis [84]. One study [85] found that the likelihood of experiencing a depressive episode was significantly reduced among individuals with at least one Met allele of $B D N F$ but only in the absence of a severe stressful event. It is possible that interventions that focus on providing supportive and positive environments would be most beneficial to individuals who are genetically sensitivity to stress.

The aetiology of psychiatric disorders such as major depression is complex and is likely to involve multiple interactions between genetic variants and environmental factors. Few studies have explored the three-way interaction between childhood adversity, stressful life events and stress vulnerability genetic variants [86]. A wealth of research shows that adversity in childhood sensitises individuals to adult stressful life events increasing their risk for major depression [87]. Given the mounting evidence that genetic variants such as BDNF Val66Met polymorphism are important stress vulnerability factors sets the stage for future studies that should explore the childhood adversity $\times$ stressful life events $\times B D N F$ interaction in the context of depression.

\section{Child adversity}

When examining the specific influence of child adversity, 4 out of 16 studies reported a significant interaction with $B D N F$ Val66Met for depression, and 5 were able to provide partial support for this interaction [65-68]. However, the results from the meta-analysis of these studies provided only a trend towards a significant effect.

On closer inspection of these results it appears that the childhood adversity-BDNF relationship in depression may be complex, with some studies reporting a significant interaction among women and not men [68,73], and for specific subtypes of depression (non-melancholic) [65]. In addition, specific forms of childhood adversity maybe driving these associations (for example, child sexual abuse [66]). More research in this area is warranted focusing on specific forms of adversity and depression subtypes as well as investigating gender differences.

The non-replicating studies have two characteristics that are noteworthy. Firstly, some studies which failed to detect any evidence for a child adversity $\times B D N F$ in depression used child and adolescent cohorts $[79,80]$. Secondly, more reliable (for example, interviews [80,81]) and objective measures [79] of childhood adversity were adopted by these studies in comparison to those which found evidence for a gene-environment interaction who mainly used questionnaires (for example, $[74,76]$ ). There are several possible explanations for these null findings. The interaction between child adversity and BDNF may be developmentally sensitive and only manifests later in life (beyond adolescence). It is also possible that the $B D N F$-childhood adversity relationship in depression is a measurement artefact. Thus, future studies should assess an adult sample using interviews or objective measures of child adversity.

\section{Stressful life events}

The results of the meta-analysis showed that the effect of stressful life events on depression is significantly moderated by the BDNF polymorphism. The majority of the positive studies measured stressful events using researcher-administered questionnaires or interviews while the majority of the non-replicating studies utilised self-report checklists. It is possible that more objective and sensitive approaches to measuring stressful life events are required to observe its interaction with $B D N F$ in depression.

\section{BDNF}

The $B D N F$ gene consists of a number of polymorphisms which may also be relevant for gene-environment interactions in depression [55]. The majority of published studies have focused BDNF Val66Met, which allows for the present meta-analysis, but it would be useful for future studies to explore the relationship between other $B D N F$ polymorphisms and stress in depression.

\section{Limitations}

The studies reviewed in this article are subject to a number of limitations. Firstly, different life stress measures were employed. Questionnaires present the biggest challenge as they rely on self-report and are vulnerable to various biases such as the participant's subjective interpretation of what counts as an event and enquire about a restricted number of events. Despite these limitations, most studies relied on self-report questionnaires, casting doubt on their results. Some studies have attempted to overcome these problems by using trained researchers to administer the questionnaires providing some improvement. More robust methods, such as life stress interviews or use of social services 
records of child maltreatment are more objective and combat many of the biases associated with self-report.

Secondly, the majority of included studies used Caucasian samples, which may have influenced the results. It is possible that the $B D N F \times$ stress in depression is only relevant to Caucasian populations, although significant interactions have been reported among Asian [43] and ethnically mixed populations [76,77]. Future studies need to recruit participants from non-Caucasian backgrounds to test the generalisability of the $B D N F \times$ stress in depression to other ethnic groups.

Thirdly, several included studies may have limited power due to their restricted sample sizes (for example, [65,78]). For the current study, power analyses revealed that using the pooled samples provided greater than $80 \%$ power to detect significant effects of all three interactions tested in this project (these are, (1) life stress $\times B D N F$, (2) childhood adversity $\times B D N F$, (3) stressful life events $\times B D N F$ in depression).

Finally, the statistical approach used to conduct the current meta-analysis relied on combining the $P$ values of existing studies, which were weighted by sample size. This approach was adopted to maximise the number of studies that could be included, with the aim of reducing biases associated with selecting a homogeneous set of studies and to better reflect the current evidence in this field. The meta-analytic method of combining $P$ values could be improved upon by using traditional approaches that focus on combining effect sizes, which benefit from providing the magnitude of an effect.

\section{Conclusions}

A total of 22 studies with a pooled sample of 14,233 individuals were included in this review, of which 8 provided evidence in support of an interaction between life stress and the BDNF Val66Met polymorphism in depression. A meta-analysis provided evidence for an interaction between the Met variant of the $B D N F$ Val66Met polymorphism and life stress in the causation of depression. When stratified by the type of stress, the results of the meta-analyses were only significant for stressful life events and not childhood adversity. This suggests that serotonin transporter and BDNF genes may confer sensitivity to early and late environmental factors respectively and play complementary yet distinct roles in the depression aetiology.

\section{Additional file}

Additional file 1: Table S1. Quality assessment of brain-derived neurotrophic factor (BDNF), life stress and depression studies $[43,65-71,73-83,85,88,89]$.

\section{Authors' contributions}

GMH was responsible for drafting the manuscript and collation of the data for analysis. KET undertook the analyses for the study, contributed to collation and checking the data. CS conducted the initial literature search and collation of data. RU and PMcG contributed to the design of the study and interpretation of the results. All authors were involved in drafting the manuscript and have given final approval of the version to be published.

\section{Acknowledgements}

We would like to express our gratitude to Siobhan Lynch for her input into and comments on early drafts of this manuscript. We are grateful to Annette La Greca, Betty Lai, Kent Nilsson, Gabriella Juhasz, Marieke Wichers, Joan Kaufman, Justine Gatt, Andrew Kemp, Esther Nederhof, George Brown, Lourdes Fañanas, Maria Claudia Lattig, Jin-Sang Yoon, Silvia Alemany, Hans Grabe and Christian Schwan for providing supplementary information on their studies. GMH was supported by a Medical Research Council (MRC) and Economic Social Research Council (ESRC) UK Interdisciplinary Postdoctoral Fellowship (PTA-037-27-0165) at the time of writing the paper. RU is supported by the Canada Research Chairs program (http://www.chairs-chaires.gc.ca/ home-accueil-eng.aspx). The funding sources had no role in designing the present study, writing the manuscript or the decision to submit.

\section{Author details}

${ }^{1}$ Psychology Department, Goldsmiths, University of London, New Cross, London SE14 6NW, UK. ${ }^{2}$ MRC Social, Genetic and Developmental Psychiatry Centre, Institute of Psychiatry, King's College, London, De Crespigny Park, London SE5 8AF, UK. 'King's College London, Academic Centre, 2nd Floor Henriette Raphael House, Guy's Campus, London SE1 1UL UL, UK. ${ }^{4}$ MRC Centre for Neuropsychiatric Genetics and Genomics, Department of Psychological Medicine and Neurology, School of Medicine, Cardiff University, Cardiff CF24 4HQ, UK. ${ }^{5}$ Department of Psychiatry, Dalhousie University, 5909 Veterans' Memorial Lane, Halifax, Nova Scotia B3H 2E2, Canada.

Received: 26 April 2013 Accepted: 24 December 2013

Published: 16 January 2014

\section{References}

1. McGuffin P: Affective disorders. In Essential Psychiatry. Edited by Murray RM, Kendler KS, McGuffin P, Wessely S, Castle D. Cambridge, UK: Cambridge University Press; 2008:250-283.

2. Alloy LB, Abramson LY, Smith JM, Gibb BE, Neeren AM: Role of parenting and maltreatment histories in unipolar and bipolar mood disorders: mediation by cognitive vulnerability to depression. Clin Child Fam Psychol Rev 2006, 9:23-64.

3. Fisher H, Hosang GM: Childhood maltreatment and bipolar disorder: a critical review of the evidence. Mind Brain J Psychiatr 2010, 1:75-85.

4. Hosang GM, Korszun A, Jones L, Jones I, Gray JM, Gunasinghe CM, McGuffin $P$, Farmer AE: Adverse life event reporting and worst illness episodes in unipolar and bipolar affective disorders: measuring environmental risk for genetic research. Psychol Med 2010, 40:1829-1837.

5. Farmer AE, McGuffin P: Humiliation, loss and other types of life events and difficulties: a comparison of depressed subjects, healthy controls and their siblings. Psychol Med 2003, 33:1169-1175.

6. Hammen C: Stress and depression. Annu Rev Clin Psychol 2005, 1:293-319.

7. Caspi A, Hariri AR, Holmes A, Uher R, Moffitt TE: Genetic sensitivity to the environment: the case of the serotonin transporter gene and its implications for studying complex diseases and traits. Am J Psychiatry 2010, 167:509-527.

8. Groves JO: Is it time to reassess the BDNF hypothesis of depression? Mol Psychiatry 2007, 12:1079-1088.

9. Stein DJ, Daniels WMU, Savitz J, Harvey BH: Brain-derived neurotrophic factor: the neurotrophin hypothesis of psychopathology. CNS Spectr 2008, 13:945-949.

10. Kessler RC, Chiu WT, Demler O, Merikangas KR, Walters EE: Prevalence, severity, and comorbidity of 12-month DSM-IV disorders in the National Comorbidity Survey Replication. Arch Gen Psychiatry 2005, 62:617-627.

11. Miklowitz DJ, Johnson SL: The psychopathology and treatment of bipolar disorder. Annu Rev Clin Psychol 2006, 2:199-235. 
12. Lopez AD, Mathers CD, Ezzati M, Jamison DT, Murray CJ: Global and regional burden of disease and risk factors, 2001: systematic analysis of population health data. Lancet 2006, 367:1747-1757.

13. Menken M, Munsat TL, Toole JF: The global burden of disease study: implications for neurology. Arch Neurol 2000, 57:418-420.

14. Fisher HL, Cohen-Woods S, Hosang GM, Korszun A, Owen M, Craddock N, Craig IW, Farmer AE, McGuffin P, Uher R: Interaction between specific forms of childhood maltreatment and the serotonin transporter gene (5-HTT) in recurrent depressive disorder. J Affect Disord 2013, 145:136-141.

15. Nanni $V$, Uher R, Danese A: Childhood maltreatment predicts unfavorable course of illness and treatment outcome in depression: a meta-analysis. Am J Psychiatry 2012, 169:141-151.

16. Scott KM, McLaughlin KA, Smith DA, Ellis PM: Childhood maltreatment and DSM-IV adult mental disorders: comparison of prospective and retrospective findings. Br J Psychiatry 2012, 200:469-475.

17. Widom CS, DuMont K, Czaja SJ: A prospective investigation of major depressive disorder and comorbidity in abused and neglected children grown up. Arch Gen Psychiatry 2007, 64:49-56.

18. Agnafors S, Comasco E, Bladh M, Sydsjo G, Dekeyser L, Oreland L, Svedin CG: Effect of gene, environment and maternal depressive symptoms on pre-adolescence behavior problems - a longitudinal study. Child Adolesc Psychiatry Ment Health 2013, 7:10.

19. Morgan C, Fisher $\mathrm{H}$ : Environment and schizophrenia: environmental factors in schizophrenia: childhood trauma-a critical review. Schizophr Bull 2007, 33:3-10.

20. Kessler RC, McLaughlin KA, Green JG, Gruber MJ, Sampson NA, Zaslavsky AM, Aguilar-Gaxiola S, Alhamzawi AO, Alonso J, Angermeyer M, Benjet C, Bromet E, Chatterij S, de Girolamo G, Demyttenaere K, Fayyad J, Florescu S, Gal G, Gureje O, Haro JM, Hu CY, Karam EG, Kawakami N, Lee S, Lépine JP, Ormel J, Posada-Villa J, Sagar R, Tsang A, Ustün TB, et al: Childhood adversities and adult psychopathology in the WHO World Mental Health Surveys. Br J Psychiatry 2010, 197:378-385.

21. Hosang GM, Johnson SL, Kiecolt-Glaser J, Di Gregorio MP, Lambert DR, Bechtel MA, Hearne DW, Herron JB, Glaser R: Gender specific association of child abuse and adult cardiovascular disease in a sample of patients with basal cell carcinoma. Child Abuse Negl 2013, 37:374-379.

22. Scott KM, Von Korff M, Angermeyer MC, Benjet C, Bruffaerts R, de Girolamo G, Haro JM, Lépine JP, Ormel J, Posada-Villa J, Tachimori H, Kessler RC: Association of childhood adversities and early-onset mental disorders with adult-onset chronic physical conditions. Arch Gen Psychiatry 2011, 68:838-844.

23. Ezquiaga E, Ayuso Gutierrez JL, Garcia Lopez A: Psychosocial factors and episode number in depression. J Affect Disord 1987, 12:135-138.

24. Hosang GM, Korszun A, Jones L, Jones I, McGuffin P, Farmer AE: Life-event specificity: bipolar disorder compared with unipolar depression. Br J Psychiatry 2012, 201:458-465.

25. Hosang GM, Uher R, Maughan B, McGuffin P, Farmer AE: The role of loss and danger events in symptom exacerbation in bipolar disorder. J Psychiatr Res 2012, 46:1584-1589.

26. Brown GW, Harris TO: Social Origins of Depression. A Study of Psychiatric Disorder in Women. London, UK: Routledge; 1978.

27. Uher R, McGuffin P: The moderation by the serotonin transporter gene of environmental adversity in the aetiology of mental illness: review and methodological analysis. Mol Psychiatry 2008, 13:131-146.

28. Uher $R$, McGuffin $P$ : The moderation by the serotonin transporter gene of environmental adversity in the etiology of depression: 2009 update. Mol Psychiatry 2010, 15:18-22.

29. Monroe SM, Reid MW: Gene-environment interactions in depression research: genetic polymorphisms and life-stress polyprocedures. Psychol Sci 2008, 19:947-956.

30. Maciejewski PK, Prigerson HG, Mazure CM: Sex differences in event-related risk for major depression. Psychol Med 2001, 31:593-604.

31. Caspi A, Sugden K, Moffitt TE, Taylor A, Craig IW, Harrington H, McClay J, Mill J, Martin J, Braithwaite A, Poulton R: Influence of life stress on depression: moderation by a polymorphism in the 5-HTT gene. Science 2003, 301:386-389.

32. Uher R: Forum: The case for gene-environment interactions in psychiatry. Curr Opin Psychiatry 2008, 21:318-321.

33. Moffitt TE, Caspi A, Rutter M: Strategy for investigating interactions between measured genes and measured environments. Arch Gen Psychiatry 2005, 62:473-481.

34. Eley TC, Sugden K, Corsico A, Gregory AM, Sham P, McGuffin P, Plomin R, Craig IW: Gene-environment interaction analysis of serotonin system markers with adolescent depression. Mol Psychiatry 2004, 9:908-915.
35. Surtees PG, Wainwright NW, Willis-Owen SA, Luben R, Day NE, Flint J: Social adversity, the serotonin transporter (5-HTTLPR) polymorphism and major depressive disorder. Biol Psychiatry 2006, 59:224-229.

36. Brown GW, Harris TO: Depression and the serotonin transporter 5-HTTLPR polymorphism: a review and a hypothesis concerning gene-environment interaction. J Affect Disord 2008, 111:1-12.

37. Karg K, Burmeister M, Shedden K, Sen S: The serotonin transporter promoter variant (5-HTTLPR), stress, and depression meta-analysis revisited: evidence of genetic moderation. Arch Gen Psychiatry 2011, 68:444-454.

38. Brown GW, Ban M, Craig TK, Harris TO, Herbert J, Uher R: Serotonin transporter length polymorphism, childhood maltreatment, and chronic depression: a specific gene-environment interaction. Depress Anxiety 2013, 30:5-13.

39. Uher R, Caspi A, Houts R, Sugden K, Williams B, Poulton R, Moffitt TE: Serotonin transporter gene moderates childhood maltreatment's effects on persistent but not single-episode depression: replications and implications for resolving inconsistent results. J Affect Disord 2011, 135:56-65.

40. Polanczyk G, Caspi A, Williams B, Price TS, Danese A, Sugden K, Uher R, Poulton R, Moffitt TE: Protective effect of CRHR1 gene variants on the development of adult depression following childhood maltreatment: replication and extension. Arch Gen Psychiatry 2009, 66:978-985.

41. Bradley RG, Binder EB, Epstein MP, Tang Y, Nair HP, Liu W, Gillespie CF, Berg T, Evces M, Newport DJ, Stowe ZN, Heim CM, Nemeroff CB, Schwartz A, Cubells JF, Ressler KJ: Influence of child abuse on adult depression: moderation by the corticotropin-releasing hormone receptor gene. Arch Gen Psychiatry 2008, 65:190-200.

42. Zimmermann P, Bruckl T, Nocon A, Pfister $H$, Binder EB, Uhr M, Lieb R, Moffitt TE, Caspi A, Holsboer F, Ising M: Interaction of FKBP5 gene variants and adverse life events in predicting depression onset: results from a 10-year prospective community study. Am J Psychiatry 2011, 168:1107-1116.

43. Kim JM, Stewart R, Kim SW, Yang SJ, Shin IS, Kim YH, Yoon JS: Interactions between life stressors and susceptibility genes (5-HTTLPR and BDNF) on depression in Korean elders. Biol Psychiatry 2007, 62:423-428.

44. Post RM: Role of BDNF in bipolar and unipolar disorder: clinical and theoretical implications. J Psychiatr Res 2007, 41:979-990.

45. Duman RS, Monteggia LM: A neurotrophic model for stress-related mood disorders. Biol Psychiatry 2006, 59:1116-1127.

46. Nibuya M, Takahashi M, Russell DS, Duman RS: Repeated stress increases catalytic TrkB mRNA in rat hippocampus. Neurosci Lett 1999, 267:81-84

47. Roceri M, Cirulli F, Pessina C, Peretto P, Racagni G, Riva MA: Postnatal repeated maternal deprivation produces age-dependent changes of brain-derived neurotrophic factor expression in selected rat brain regions. Biol Psychiatry 2004, 55:708-714.

48. Kauer-Sant'Anna M, Tramontina J, Andreazza AC, Cereser K, da Costa S, Santin A, Yatham LN, Kapczinski F: Traumatic life events in bipolar disorder: impact on BDNF levels and psychopathology. Bipolar Disord 2007, 9:128-135.

49. Grassi-Oliveira R, Stein LM, Lopes RP, Teixeira AL, Bauer ME: Low plasma brain-derived neurotrophic factor and childhood physical neglect are associated with verbal memory impairment in major depression - a preliminary report. Biol Psychiatry 2008, 64:281-285.

50. Molendijk ML, Spinhoven P, Polak M, Bus BA, Penninx BW, Elzinga BM: Serum BDNF concentrations as peripheral manifestations of depression: evidence from a systematic review and meta-analyses on 179 associations ( $\mathrm{N}=9484)$. Mol Psychiatry. in press.

51. Sen S, Duman R, Sanacora G: Serum brain-derived neurotrophic factor, depression, and antidepressant medications: meta-analyses and implications. Biol Psychiatry 2008, 64:527-532.

52. Jiang C, Salton SR: The Role of Neurotrophins in Major Depressive Disorder. Trans/ Neurosci 2013, 4:46-58.

53. Rybakowski JK: BDNF gene: functional Val66Met polymorphism in mood disorders and schizophrenia. Pharmacogenomics 2008, 9:1589-1593.

54. Uher R, Huezo-Diaz P, Perroud N, Smith R, Rietschel M, Mors O, Hauser J, Maier W, Kozel D, Henigsberg N, Barreto M, Placentino A, Dernovsek MZ, Schulze TG, Kalember P, Zobel A, Czerski PM, Larsen ER, Souery D, Giovannini C, Gray JM, Lewis CM, Farmer A, Aitchison KJ, McGuffin P, Craig I: Genetic predictors of response to antidepressants in the GENDEP project. Pharmacogenomics J 2009, 9:225-233.

55. Liu L, Foroud T, Xuei X, Berrettini W, Byerley W, Coryell W, El-Mallakh R, Gershon ES, Kelsoe JR, Lawson WB, MacKinnon DF, Mclnnis M, McMahon FJ, Murphy DL, Rice J, Scheftner W, Zandi PP, Lohoff FW, Niculescu AB, Meyer ET, 
Edenberg HJ, Nurnberger II Jr: Evidence of association between brain-derived neurotrophic factor gene and bipolar disorder. Psychiatr Genet 2008, 18:267-274.

56. Egan MF, Kojima M, Callicott JH, Goldberg TE, Kolachana BS, Bertolino A, Zaitsev E, Gold B, Goldman D, Dean M, Lu B, Weinberger DR: The BDNF val66met polymorphism affects activity-dependent secretion of BDNF and human memory and hippocampal function. Cell 2003, 112:257-269.

57. Jiang X, Xu K, Hoberman J, Tian F, Marko AJ, Waheed JF, Harris CR, Marini AM, Enoch MA, Lipsky RH: BDNF variation and mood disorders: a novel functional promoter polymorphism and Val66Met are associated with anxiety but have opposing effects. Neuropsychopharmacology 2005, 30:1353-1361.

58. Vinberg M, Trajkovska V, Bennike B, Knorr U, Knudsen GM, Kessing LV: The BDNF Val66Met polymorphism: relation to familiar risk of affective disorder, BDNF levels and salivary cortisol. Psychoneuroendocrinology 2009, 34:1380-1389

59. Chen ZY, Jing D, Bath KG, leraci A, Khan T, Siao CJ, Herrera DG, Toth M, Yang C, McEwen BS, Hempstead BL, Lee FS: Genetic variant BDNF (Val66Met) polymorphism alters anxiety-related behavior. Science 2006, 314:140-143.

60. Murakami S, Imbe H, Morikawa Y, Kubo C, Senba E: Chronic stress, as well as acute stress, reduces BDNF mRNA expression in the rat hippocampus but less robustly. Neurosci Res 2005, 53:129-139.

61. Liberati A, Altman DG, Tetzlaff J, Mulrow C, Gotzsche PC, loannidis JP, Clarke M, Devereaux PJ, Kleijnen J, Moher D: The PRISMA statement for reporting systematic reviews and meta-analyses of studies that evaluate healthcare interventions: explanation and elaboration. BMJ 2009, 339:b2700.

62. Munafo MR, Durrant C, Lewis G, Flint J: Gene $X$ environment interactions at the serotonin transporter locus. Biol Psychiatry 2009, 65:211-219.

63. Little J, Higgins JP, loannidis JP, Moher D, Gagnon F, von Elm E, Khoury MJ, Cohen B, Davey-Smith G, Grimshaw J, Scheet P, Gwinn M, Williamson RE, Zou GY, Hutchings K, Johnson CY, Tait V, Wiens M, Golding J, van Duijn C, McLaughlin J, Paterson A, Wells G, Fortier I, Freedman M, Zecevic M, King R, Infante-Rivard C, Stewart A, Birkett N: Strengthening the reporting of genetic association studies (STREGA): an extension of the STROBE Statement. Hum Genet 2009, 125:131-151.

64. von Elm E, Altman DG, Egger M, Pocock SJ, Gotzsche PC, Vandenbroucke $J P$, Initiative S: The Strengthening the Reporting of Observational Studies in Epidemiology (STROBE) statement: guidelines for reporting observational studies. Lancet 2007, 370:1453-1457.

65. Quinn CR, Dobson-Stone C, Outhred T, Harris A, Kemp AH: The contribution of BDNF and 5-HTT polymorphisms and early life stress to the heterogeneity of major depressive disorder: a preliminary study. Aust N Z J Psychiatry 2012, 46:55-63.

66. Aguilera M, Arias B, Wichers M, Barrantes-Vidal N, Moya J, Villa H, van Os J, Ibanez MI, Ruiperez MA, Ortet G, Fananas L: Early adversity and 5-HTT/BDNF genes: new evidence of gene-environment interactions on depressive symptoms in a general population. Psychol Med 2009, 39:1425-1432.

67. Comasco E, Aslund C, Oreland L, Nilsson KW: Three-way interaction effect of 5-HTTLPR, BDNF Val66Met, and childhood adversity on depression: a replication study. Eur Neuropsychopharmacol 2013, 23:1300-1306.

68. Lavebratt C, Aberg E, Sjoholm LK, Forsell Y: Variations in FKBP5 and BDNF genes are suggestively associated with depression in a Swedish population-based cohort. J Affect Disord 2010, 125:249-255.

69. Chen J, Li X, McGue M: Interacting effect of BDNF Val66Met polymorphism and stressful life events on adolescent depression. Genes Brain Behav 2012, 11:958-965.

70. Grabe HJ, Schwahn C, Mahler J, Appel K, Schulz A, Spitzer C, Fenske K, Barnow S, Freyberger HJ, Teumer A, Petersmann A, Biffar R, Rosskopf D, John U, Völzke $\mathrm{H}$ : Genetic epistasis between the brain-derived neurotrophic factor Val66Met polymorphism and the 5-HTT promoter polymorphism moderates the susceptibility to depressive disorders after childhood abuse. Prog Neuropsychopharmacol Biol Psychiatry 2012, 36:264-270.

71. Caldwell W, McInnis OA, McQuaid RJ, Liu G, Stead JD, Anisman H, Hayley S: The role of the Val66Met polymorphism of the brain derived neurotrophic factor gene in coping strategies relevant to depressive symptoms. PLoS One 2013, 8:e65547.

72. Petryshen TL, Sabeti PC, Aldinger KA, Fry B, Fan JB, Schaffner SF, Waggoner SG, Tahl AR, Sklar P: Population genetic study of the brain-derived neurotrophic factor (BDNF) gene. Mol Psychiatry 2010, 15:810-815.

73. Wichers M, Kenis G, Jacobs N, Mengelers R, Derom C, Vlietinck R, van Os J: The BDNF Val(66)Met x 5-HTTLPR $x$ child adversity interaction and depressive symptoms: An attempt at replication. Am J Med Genet B Neuropsychiatr Genet 2008, 147B:120-123.

74. Juhasz G, Dunham JS, McKie S, Thomas E, Downey D, Chase D, Lloyd-Williams K, Toth ZG, Platt H, Mekli K, Payton A, Elliott R, Williams SR, Anderson IM, Deakin JF: The CREB1-BDNF-NTRK2 pathway in depression: multiple gene-cognitionenvironment interactions. Biol Psychiatry 2011, 69:762-771.

75. Hosang GM, Uher R, Keers R, Cohen-Woods S, Craig I, Korszun A, Perry J, Tozzi F, Muglia P, McGuffin P, Farmer AE: Stressful life events and the brain-derived neurotrophic factor gene in bipolar disorder. $J$ Affect Disord 2010, 125:345-349.

76. Carver CS, Johnson SL, Joormann J, Lemoult J, Cuccaro ML: Childhood adversity interacts separately with 5-HTTLPR and BDNF to predict lifetime depression diagnosis. J Affect Disord 2011, 132:89-93.

77. Perea CS, Paternina AC, Gomez Y, Lattig MC: Negative affectivity moderated by BDNF and stress response. J Affect Disord 2012, 136:767-774.

78. La Greca AM, Lai BS, Joormann J, Auslander BB, Short MA: Children's risk and resilience following a natural disaster: Genetic vulnerability, posttraumatic stress, and depression. J Affect Disord 2013, 151:860-867.

79. Kaufman J, Yang BZ, Douglas-Palumberi H, Grasso D, Lipschitz D, Houshyar S, Krystal JH, Gelernter J: Brain-derived neurotrophic factor-5-HTTLPR gene interactions and environmental modifiers of depression in children. Biol Psychiatry 2006, 59:673-680.

80. Nederhof E, Bouma EM, Oldehinkel AJ, Ormel J: Interaction between childhood adversity, brain-derived neurotrophic factor val/met and serotonin transporter promoter polymorphism on depression: the TRAILS study. Biol Psychiatry 2010, 68:209-212.

81. Elzinga BM, Molendijk ML, Oude Voshaar RC, Bus BA, Prickaerts J, Spinhoven $P$, Penninx $B J$ : The impact of childhood abuse and recent stress on serum brain-derived neurotrophic factor and the moderating role of BDNF Val66Met. Psychopharmacology (Berl) 2011, 214:319-328.

82. Bukh JD, Bock C, Vinberg M, Werge T, Gether U, Vedel Kessing L: Interaction between genetic polymorphisms and stressful life events in first episode depression. J Affect Disord 2009, 119:107-115.

83. Herbert J, Ban M, Brown GW, Harris TO, Ogilvie A, Uher R, Craig TK: Interaction between the BDNF gene $\mathrm{Val} / 66 /$ Met polymorphism and morning cortisol levels as a predictor of depression in adult women. Br J Psychiatry 2012, 201:313-319.

84. Belsky J, Pluess M: Beyond diathesis stress: differential susceptibility to environmental influences. Psychol Bull 2009, 135:885-908.

85. Brown GW, Craig TK, Harris TO, Herbert J, Hodgson K, Tansey KE, Uher R: Functional polymorphism in the Brain-derived neurotrophic factor gene interacts with stressful life events but not childhood maltreatment in the etiology of depression. Depress Anxiety. DOI: 10.1002/da.22221.

86. Power RA, Lecky-Thompson L, Fisher HL, Cohen-Woods S, Hosang GM, Uher R, Powell-Smith G, Keers R, Tropeano M, Korszun A, Jones L, Jones I, Owen MJ, Craddock N, Craig IW, Farmer AE, McGuffin P: The interaction between child maltreatment, adult stressful life events and the 5-HTTLPR in major depression. J Psychiatr Res 2013, 47:1032-1035.

87. Nederhof E, Schmidt MV: Mismatch or cumulative stress: toward an integrated hypothesis of programming effects. Physiol Behav 2012, 106:691-700.

88. Gatt JM, Nemeroff CB, Dobson-Stone C, Paul RH, Bryant RA, Schofield PR, Gordon E, Kemp AH, Williams LM: Interactions between BDNF Val66Met polymorphism and early life stress predict brain and arousal pathways to syndromal depression and anxiety. Mol Psychiatry 2009, 14:681-695.

89. Jiang R, Brummett BH, Babyak MA, Siegler IC, Williams RB: Brain-derived neurotrophic factor (BDNF) Val66Met and adulthood chronic stress interact to affect depressive symptoms. J Psychiatr Res 2013, 47:233-239.

doi:10.1186/1741-7015-12-7

Cite this article as: Hosang et al:: Interaction between stress and the $B D N F$ Val66Met polymorphism in depression: a systematic review and meta-analysis. BMC Medicine 2014 12:7. 